PINHEIRO, JB; SILVA, GO; BISCAIA, D; MACEDO, AG; SUINAGA, FA. 2020. Characterization of lettuce genotypes for resistance to root-knot nematodes (Meloidogyne spp.). Horticultura Brasileira 38: 239-245. DOI - http://dx.doi.org/10.1590/S0102-053620200301.

\title{
Characterization of lettuce genotypes for resistance to root-knot nematodes (Meloidogyne spp.)
}

\author{
Jadir B Pinheiro ${ }^{1} \mathbb{D}$; Giovani Olegário da Silva ${ }^{2} \mathbb{D}$; Danielle Biscaia ${ }^{1} \mathbb{D}$; Amanda G Macedo ${ }^{3} \mathbb{D}$; Fábio A \\ Suinaga ${ }^{1} \mathbb{D}$
}

${ }^{1}$ Embrapa Hortaliças, Brasília-DF, Brasil; jadir.pinheiro@embrapa.br; danielle.biscaia@embrapa.br; fabio.suinaga@embrapa.br; ${ }^{2}$ Embrapa Hortaliças, EE de Canoinhas, Canoinhas-SC, Brasil; giovani.olegario@embrapa.br; ${ }^{3}$ Universidade de Brasília (UnB), Brasília-DF, Brasil; amandagomesma@gmail.com

\begin{abstract}
Genetic resistance is the most suitable mechanism to control root-knot nematodes in lettuce. However, information about the resistance levels of currently used lettuce cultivars is scarce in the literature. Thus, the objective of this research was to characterize lettuce cultivars for resistance to root-knot nematodes Meloidogyne incognita $(\mathrm{Mi})$ and $M$. javanica $(\mathrm{Mj})$, aiming the identification of resistance sources for breeding, and to transfer information to the productive sector. We evaluated 97 lettuce genotypes in tree trials. In the first one (preliminary assessment), 92 lettuce genotypes were inoculated simultaneously with $M$. incognita race 1 and $M$. javanica species, 17 days after sowing. The gall index (GI) was evaluated 41 days after inoculation. In the second trial nine genotypes, selected from the first trial, were evaluated; and in the third trial, two new cultivars from Embrapa were evaluated. In the last two trials, the nematode species were inoculated separately, and the egg mass index (EMI), number of eggs per gram of roots (NEGR) and reproduction factor (RF) were also evaluated. In both trials, the lettuce cultivars Salinas 88 and Grand Rapids were used as resistant controls, as well as cultivar Irene as the susceptible control. The data were submitted to analysis of variance and treatments means grouping by Scott-Knott's test. The crisp leaf cultivars presented a higher degree of resistance to the root-knot nematodes compared to the smooth leaf type cultivars. Cultivars Vera and Amanda present resistance to $M$. incognita, and Vanda to $M$. javanica. 'Salinas 88 ' present resistance mainly to $M$. javanica; while cultivar Mônica and the Embrapa cultivars BRS Leila and BRS Mediterrânea are resistant to both nematode species.
\end{abstract}

Keywords: Lactuca sativa, M. incognita, M. javanica, reproduction factor.

\section{RESUMO}

Caracterização de genótipos de alface quanto à resistência ao nematoide-das-galhas (Meloidogyne spp.)

Aresistência genética é o mecanismo mais indicado para o controle dos nematoides-das-galhas em alface. No entanto são escassas na literatura informações sobre os níveis de resistência das principais cultivares de alface utilizadas atualmente no país. Dessa forma, o objetivo do trabalho foi caracterizar genótipos de alface quanto à resistência aos nematoides-das-galhas, Meloidogyne incognita (Mi) e $M$. javanica $(\mathrm{Mj})$, visando a identificação de fontes de resistência para utilização no melhoramento, e o repasse de informações para o setor produtivo. Foram avaliados no total 97 genótipos de alface em três diferentes ensaios. No primeiro experimento (avaliação preliminar), 92 genótipos de alface foram inoculados com as espécies M. incognita raça 1 e $M$. javanica, simultaneamente, 17 dias após semeadura. Quarenta e um dias após a inoculação avaliou-se o índice de galhas (GI) nas raízes. No segundo ensaio foram avaliados nove genótipos, selecionados a partir do primeiro ensaio, e no terceiro ensaio duas novas cultivares lançadas pela Embrapa; sendo que nesses dois últimos ensaios as espécies de nematoides foram inoculadas separadamente e avaliado também o Índice de Massa de Ovos (EMI), Número de Ovos por Grama de Raízes (NEGR) e o Fator de Reprodução (RF). Somados aos genótipos avaliados em cada ensaio, foram utilizadas como testemunhas resistentes as cultivares de alface Salinas 88 e Grand Rapids, e como suscetível a cultivar Irene. Os dados foram submetidos a análise de variância e agrupamento de médias dos tratamentos por Scott-Knott. Foi possível concluir que as cultivares do tipo crespa apresentaram maior grau de resistência aos nematoides-das-galhas em comparação às cultivares do tipo lisa. As cultivares Vera e Amanda apresentam resistência a $M$. incognita, e Vanda a $M$. javanica. Salinas 88 apresenta resistência principalmente a M. javanica; enquanto a cultivar Mônica e as cultivares da Embrapa BRS Leila e BRS Mediterrânea, são resistentes a ambas as espécies de nematoides.

Palavras-chave: Lactuca sativa, M. incognita, M. javanica, Fator de Reprodução.

\section{Received on November 11, 2019; accepted on April 8, 2020}

$\mathrm{L}$ ettuce (Lactuca sativa) is the most important leafy vegetable in Brazil, being consumed in natura as salad. However, due to intensive cultivation of this vegetable, and because most lettuce cultivars are highly susceptible to root-knot nematodes (Campos et al., 2001; Pinheiro, 2017), the nematode populations have increased in production areas, causing considerable economic damages (Rabello, 2010; Pinheiro, 2017). Among the nematodes, 
important for lettuce cultivation, the species Meloidogyne incognita and $M$. javanica stand out. The galls formed in the roots, due to penetration and infection by Meloidogyne, difficult the absorption of water and soil nutrients, resulting in yellowish plants, with reduced size, lower leaf volume, and without economic value, in addition to shortening the vegetative cycle and in some cases leading many seedlings to death (Rabello, 2010; Oliveira et al., 2015; Pinheiro, 2017).

Among the control methods available, the nematicides are not recommended, because the lettuce is a leafy vegetable with very short vegetative cycle, furthermore, do not exist nematicides registered for this crop. The crop rotation is often rejected by producers, because they need to earn income in small areas in an intensive way (Dutra et al., 2003). Therefore, the use of resistant cultivars is considered ideal to control nematodes (Wilcken $e t$ al., 2005; Oliveira et al., 2015). The genetic resistance of cultivars Salinas 88 (Carvalho Filho et al., 2007) and Grand Rapids (Gomes et al., 2000) to $M$. incognita, is assumed to be due to dominant genes with additive action to resistance, which facilitates obtaining resistant materials in breeding. However, are scarce in the literature informations about the levels of resistance of the main lettuce cultivars currently used in the country. Thus, the characterization of the resistance level of cultivars, besides being important for research, it is also important as information for the productive sector, that can choose the most resistant cultivars for their cultivation.

Thus, the objective of this research was to characterize lettuce cultivars for resistance to root-knot nematodes Meloidogyne incognita (Mi) and M. javanica $(\mathrm{Mj})$, aiming at the identification of resistance sources for breeding, and the transfer of information to the productive sector.

\section{MATERIAL AND METHODS}

The trials were conducted in a greenhouse, and the samples evaluated in the Nematology Laboratory of
Embrapa Hortaliças, Brasília-DF, Brazil, between September and November 2011 (first trial), from April to June 2012 (second trial) and from September to November 2016 (third trial). Ninetythree, nine, and two lettuce genotypes, were evaluated in the first, second and third trials, respectively, plus three standard cultivars. Five of the nine genotypes in the second trial were selected because they presented a higher degree of resistance in the first trial, three because they were grouped in the second group of more resistant genotypes, and one because it was the most susceptible. And the two genotypes of the third trial were chosen because they were promoted as cultivars more recently by Embrapa, requiring proof of the degree of resistance to these nematode species. In all trials, we used as resistant controls the lettuce cultivars Salinas 88 (American) and Grand Rapids (crisp), as susceptible the cultivar Irene (American), and to verify the inoculum viability, tomato plants of cultivar Rutgers.

In the preliminary assessment (first essay) the nematode species $M$. incognita race 1 and $M$. javanica were inoculated simultaneously laying 3,000 eggs and eventual juveniles of second stage (J2) of each species, over the soil, around the plants, 17 days after sowing in 84 cells polystyrene trays containing substrate composed of expanded vermiculite, organic matter, macro and micronutrients. In this phase, ninety-six lettuce cultivars were evaluated in a complete randomized design with 12 replications.

In the other essays (second and third) being held in pots, the experimental design was in completely randomized blocks with 6 replications being each plot composed of 1 plant/pot. Previously, seeds were sown in 84 cells polystyrene trays containing substrate composed of expanded vermiculite, organic matter, macro and micronutrients. Twelve and 29 days after sowing, respectively for the second and third trials, the plants were transplanted to $1.5-\mathrm{L}$ plastic pots, containing substrate on the proportion 1:1:1:1 of subsurface soil (a clay Oxisol, typically encountered in the Savanna Biome region in Brazil), washed sand, cow manure and carbonized rice husk mix, autoclaved at $121^{\circ} \mathrm{C}$ for $60 \mathrm{~min}$.

In the second and third essays, the plant inoculation was accomplished laying 5000 eggs and eventual juveniles of second stage (J2) separately from each species, $M$. incognita race 1 and M. javanica, over the soil, around the plants.

Forty-one days after inoculation, in the first essay, we evaluated the Gall Index (GI) in the root system of each plant according to the grades scale proposed by Taylor \& Sasser (1978), where $0=$ roots without galls; $1=$ with 1 to 2 galls; $2=3$ to 10 galls; $3=11$ to 30 galls; $4=31$ to 100 galls and $5=$ more than 100 galls.

In the second and third essays, 54 and 52 days after inoculations, respectively, the Gall Index (GI) and Egg Mass Index (EMI), were evaluated according Taylor $\&$ Sasser (1978); and the number of eggs per root gram (NEGR), the Reproduction factor $(\mathrm{RF}=$ Final population/Initial population)(5,000 eggs and J2 juveniles) and the Reactions of resistance: $\mathrm{I}=$ Immune $(\mathrm{RF}=0) ; \mathrm{R}=\mathrm{Resistant}(\mathrm{RF}<1)$ and $\mathrm{S}=$ Susceptible $(\mathrm{RF}>1)$, according to Oostenbrink (1966), were also evaluated.

Data were subjected to normality test followed by one-way analysis of variance (ANOVA) and means were grouped using the Scott-Knott clustering test at 0.05 significance level, using Genes software (Cruz, 2016).

\section{RESULTS AND DISCUSSION}

The 'Rutgers' tomato used in the essays to verify the inoculum viability, showed, as expected, susceptibility and higher number of galls, eggs, egg masses, and higher reproduction factor, indicating that inoculation and inoculum quality were satisfactory, contributing to the reliability of the observations and results (Tables 1, 2 and 3).

In the first trial, the evaluated cultivars were divided into six resistance levels, based on the groupings of mean Gall Index (GI) performed by the ScottKnott's test $(\mathrm{p}<0.05)$ (Table 1).

Among the evaluated genotypes, cultivars Vera, Vanda, Mônica, Veneranda, Amanda and Cinderela 
Crespa II were considered the most resistant, with GI of 1.42 to 2.03 ; followed by the second more resistant group, with 18 genotypes, and GI of 2.08 to 2.42 . Another group of 24 genotypes with GI of 2.51 to 3.15; one group of 25 genotypes with GI of 3.17 to 3.74 ; another group with 10 genotypes with GI of 3.96 to 4.38 , and the last group with the most susceptible 12 genotypes, including the susceptibility standard Irene, with GI of 4.42 to 4.91 , being mostly of the smooth type (Table 1).

The cultivars Salinas 88 (Charchar \& Moita, 1996; Wilcken et al., 2005; Carvalho Filho et al., 2007; Correia et al., 2019) and Grand Rapids (Charchar \& Moita, 1996; Mendes, 1998; Gomes et al., 2000; Ferreira et al., 2013) used as resistant standards to $M$. incognita and $M$. javanica, presented, in this preliminary evaluation, reaction of resistance, comparing with the other evaluated genotypes, belonging to intermediate groups with GI of 2.80 to 2.71 , respectively; indicating that in this study there are cultivars with potential to have even greater resistance than the controls.

The results of high degree of susceptibility obtained for the cultivars Vitória de Santo Antão and Elisa, corroborate the results obtained by Wilcken et al. (2004).

We observed in general, mainly in this first study, that the smooth type cultivars had a higher Gall Index compared to the crisp cultivars, which could be an indication of a higher degree of susceptibility. These results agree with Charchar \& Moita (1996), which verified that crisp lettuce cultivars presented higher resistance to the rootknot nematodes Meloidogyne incognita race 1 and $M$. javanica.

After the preliminary evaluation, for the second and third trials, studying a smaller number of genotypes, in addition to the Gall Index (GI), which refers to the quantification of the number of galls formed in plant roots, other characters were also included, as the Egg Mass Index (EMI), which refers to the quantification of the number of nematode egg masses present in the roots. The number of eggs and eventual $2^{\text {nd }}$ stage juveniles $(\mathrm{J} 2)$ extracted from the root system, quantified per root gram (NEGR) and the reproduction factor (RF), refer to the rate between the number of eggs and $\mathrm{J} 2$ found in the sample at the end of the trial, and the number of eggs and any inoculated $\mathrm{J} 2$. The evaluation based on these additional characters, used for the prospection of sources of resistance to nematodes, provides a more accurate characterization of the degree of resistance, because it allows accessing better information about the reaction of the genotypes under study, mainly the Reproduction Factor, which demonstrates the genotype's ability to increase or decrease the initial inoculated population. As they are different processes, although related, different genetic actions of resistance may be involved. Because gall infection and formation is genetically influenced, as is the process of egg mass formation and egg deposition in the roots (Libânio, 2005; Soares, 2017), allowing a new multiplication cycle and different reproductions factors.

We observed in the second experiment, that the cultivars Amanda, Babá de Verão, Mônica and Vera had reproduction factors less than 1 to $M$. incognita race 1 . To $M$. javanica a greater number of genotypes was considered resistant, these being Babá de Verão, Delícia, Grand Rapids, Mônica, Salinas 88, Tainá and Vanda. So in this experiment just 'Babá de Verão' and 'Mônica' were considered resistant to both nematode species; while the two cultivars used as standard of resistance Grand Rapids and Salinas 88, were resistant only to M. javanica (Table 2).

About the third experiment, despite higher values of the reproduction factor for $M$. incognita, the same reaction pattern was observed for genotypes evaluated for the two nematode species tested. The lettuce cultivar Grand Rapids was the most susceptible one, while the cultivar Salinas 88, together with the new cultivars of Embrapa BRS Leila and BRS Mediterrânea, were considered resistant (Table 3 ).

Comparing the results of the first and second experiments, among the most resistant cultivars from the first study, 'Mônica' was confirmed as resistant to both nematode species in the second study, while 'Amanda' and 'Vera' were resistant to $M$. incognita, and 'Vanda' only to M.javanica. 'Veneranda', which was also classified as resistant in the first experiment, in the second one showed the reproduction factor higher than the unit for the two nematodes; although it had some degree of resistance to $M$. incognita, as it did not differ statistically from the most resistant genotypes. 'Babá de Verão' was the cultivar with the most contrasting results in the two experiments, being considered the most susceptible in the first study, however as resistant to both species in the second.

This difference between the two essays can be attributed to different resistance measurements in different phases of the nematode development, as previously mentioned, the genetic control of the different phases (gall formation, egg mass formation and oviposition) occurr differently. In both experiments 'Veneranda' showed a reduced GI value, however, in the second experiment the value of RF was higher than the unit, indicating that, for this cultivar, even though there is formation of fewer number of galls and of egg masses, the amount of eggs produced was higher than the inoculated, and according to this concept, the cultivar is classified as susceptible. 'Babá de Verão' was characterized by presenting a greater number of galls and egg masses, mainly for $M$. incognita, but fewer eggs in relation to the inoculated amount (RF); therefore, it is classified as resistant.

Ferreira et al. (2018) evaluated the cultivars Babá de Verão, Veneranda, Tainá, Grand Rapids and Vera, for its reaction to $M$. incognita race 1 , all cultivars were susceptible; with reproduction indexes lower for 'Veneranda' (23.50\%) and 'Grand Rapids' (16.90\%). These authors used the reproduction index, considering the final amount of nematodes found in the lettuce genotypes in relation to the total found in the tomato Santa Clara, in percentage. These results are in agreement with those obtained in the present work, except for 'Babá de Verão' in the second experiment.

Fernandes \& Kulczynski (2009) also classified the cultivar Tainá as 
Table 1. Preliminary evaluation of commercial lettuce cultivars for resistance to a population mix of Meloidogyne incognita race 1 and M. javanica based on Gall Index (GI) evaluated from September to November 2011. Brasília, Embrapa, 2019.

\begin{tabular}{|c|c|c|c|c|c|}
\hline Cultivar & Type & GI $^{1}$ & Cultivar & Type & GI $^{1}$ \\
\hline Babá de Verão & Smooth & $4.91 \mathrm{a}$ & Maravilha de Inverno & Smooth & $2.98 \mathrm{~d}$ \\
\hline Elisabeth & Smooth & $4.74 \mathrm{a}$ & Lavine & Crisp & $2.96 \mathrm{~d}$ \\
\hline Saia Velha & Smooth & $4.69 \mathrm{a}$ & Salad Bowl & Mimosa & $2.92 \mathrm{~d}$ \\
\hline Karla & Smooth & $4.66 \mathrm{a}$ & Amélia & American & $2.89 \mathrm{~d}$ \\
\hline Lídia & Smooth & $4.66 \mathrm{a}$ & Luiza & Romaine & $2.88 \mathrm{~d}$ \\
\hline Vitória de Santo Antão & Smooth & $4.62 \mathrm{a}$ & Mimosa Bolinha & Mimosa & $2.88 \mathrm{~d}$ \\
\hline Maravilha Quatro Estações & Smooth (Manteiga) & $4.57 \mathrm{a}$ & Solaris & Crisp & $2.87 \mathrm{~d}$ \\
\hline Elisa & Smooth & $4.56 \mathrm{a}$ & Grega & Mimosa & $2.87 \mathrm{~d}$ \\
\hline Rainha de Maio & Smooth & $4.53 \mathrm{a}$ & Amx1-108 F5 Gisele x Vanda & Crisp & $2.86 \mathrm{~d}$ \\
\hline Red Salad Bown Ultra Rosso & Mimosa & $4.46 \mathrm{a}$ & Lavinia & Mimosa & $2.85 \mathrm{~d}$ \\
\hline Benta (parma) 3 Star & Romaine & $4.42 \mathrm{a}$ & Isabela & Crisp & $2.80 \mathrm{~d}$ \\
\hline Raider Plus GX635 & American & $4.38 \mathrm{~b}$ & Donna & Romaine & $2.77 \mathrm{~d}$ \\
\hline Mimosa Vermelha & Mimosa & $4.36 \mathrm{~b}$ & Grega & Mimosa & $2.72 \mathrm{~d}$ \\
\hline Roxane & Crisp & $4.30 \mathrm{~b}$ & Pira Verde & Crisp & $2.62 \mathrm{~d}$ \\
\hline Itapema 08Y2931 3 Star & Smooth & $4.21 \mathrm{~b}$ & Lente Monter New Selection & Romaine & $2.57 \mathrm{~d}$ \\
\hline Regina & Smooth & $4.21 \mathrm{~b}$ & Itapuã 401 & Crisp & $2.54 \mathrm{~d}$ \\
\hline Laurel & American & $4.20 \mathrm{~b}$ & Mauren & American & $2.52 \mathrm{~d}$ \\
\hline Romana & Romaine & $4.13 \mathrm{~b}$ & Pira Roxa & Crisp & $2.51 \mathrm{~d}$ \\
\hline Red Star & Crisp & $4.07 \mathrm{~b}$ & Paola & Crisp & $2.42 \mathrm{e}$ \\
\hline Stella & Smooth & $3.97 \mathrm{~b}$ & Roxa & Crisp & $2.42 \mathrm{e}$ \\
\hline Regina de Verão & Smooth & $3.96 \mathrm{~b}$ & Red Frizzly & Crisp & $2.40 \mathrm{e}$ \\
\hline Cerbiatta & Crisp & $3.74 \mathrm{c}$ & Cinderela & Crisp & $2.40 \mathrm{e}$ \\
\hline Sophia & Romaine & $3.71 \mathrm{c}$ & Daniele & Smooth & $2.39 \mathrm{e}$ \\
\hline Crespa Repolhuda & American & $3.70 \mathrm{c}$ & Delícia & American & $2.31 \mathrm{e}$ \\
\hline Mimosa Green Salad Bowl & Mimosa & $3.69 \mathrm{c}$ & Batavia 08Y2617 3 Star & Crisp & $2.31 \mathrm{e}$ \\
\hline Melissa & Smooth & $3.64 \mathrm{c}$ & Tainá & American & $2.31 \mathrm{e}$ \\
\hline Lucy Brown & American & $3.56 \mathrm{c}$ & Mimosa Salad Bown Roxo & Mimosa & $2.31 \mathrm{e}$ \\
\hline Todo Ano Repolhuda & Smooth & $3.55 \mathrm{c}$ & Rubra & Crisp & $2.30 \mathrm{e}$ \\
\hline Boston Branca & Smooth & $3.53 \mathrm{c}$ & Açucena 07S2306 3 Star & Crisp & $2.23 \mathrm{e}$ \\
\hline Luísa & Smooth & $3.53 \mathrm{c}$ & Veneza Roxa & Crisp & $2.23 \mathrm{e}$ \\
\hline Rafaela & American & $3.52 \mathrm{c}$ & Graciosa & Crisp & $2.22 \mathrm{e}$ \\
\hline Red Salad Bowl & Mimosa & $3.50 \mathrm{c}$ & Grandes Lagos & American & $2.18 \mathrm{e}$ \\
\hline Livia & Smooth & $3.46 \mathrm{c}$ & Ceres & Crisp & $2.17 \mathrm{e}$ \\
\hline Hanson & Crisp & $3.42 \mathrm{c}$ & Verônica & Crisp & $2.15 \mathrm{e}$ \\
\hline Green Salad Bowl & Mimosa & $3.41 \mathrm{c}$ & Green Frizzly & Crisp & $2.08 \mathrm{e}$ \\
\hline Oak Leaf Red Saladin & Mimosa & $3.35 \mathrm{c}$ & Vera & Crisp & $2.03 \mathrm{f}$ \\
\hline Romana Paris Island & Romaine & $3.35 \mathrm{c}$ & Vanda & Crisp & $2.00 \mathrm{f}$ \\
\hline Banchu New Red Fire & Crisp & $3.34 \mathrm{c}$ & Mônica & Crisp & $1.98 \mathrm{f}$ \\
\hline Rubi & Mimosa & $3.34 \mathrm{c}$ & Veneranda & Crisp & $1.86 \mathrm{f}$ \\
\hline Mirella & Mimosa & $3.33 \mathrm{c}$ & Amanda & Crisp & $1.80 \mathrm{f}$ \\
\hline Simpson & Crisp & $3.23 \mathrm{c}$ & Cinderela Crespa II & Crisp & $1.70 \mathrm{f}$ \\
\hline Angelina & American & $3.21 \mathrm{c}$ & CNPH 54 & American & $2.98 \mathrm{~d}$ \\
\hline Elba & Crisp & $3.18 \mathrm{c}$ & Irene & American & $4.74 \mathrm{a}$ \\
\hline Lady & American & $3.17 \mathrm{c}$ & Salinas 88 & American & $2.80 \mathrm{~d}$ \\
\hline Scarlet & Crisp & $3.15 \mathrm{~d}$ & Grand Rapids & Crisp & $2.71 \mathrm{~d}$ \\
\hline Sabrina 2 & Crisp & $3.06 \mathrm{~d}$ & Rutgers & Tomato & $5.00 \mathrm{a}^{2}$ \\
\hline Maravilha de Verão & Smooth & $3.05 \mathrm{~d}$ & General mean & - & 3.11 \\
\hline CNPH 54 & American & $2.98 \mathrm{~d}$ & $\mathrm{CV}^{3}(\%)$ & - & 9.44 \\
\hline
\end{tabular}

${ }^{1}$ GI: Gall Index according to Taylor \& Sasser (1978) where $0=$ roots without galls; $1=$ with 1 to 2 galls; $2=3$ to 10 galls; $3=11$ to 30 galls; $4=31$ to 100 galls; $5=$ more than 100 galls; ${ }^{2}$ Means followed by the same letter do not differ by $\operatorname{Scott}-\mathrm{Knott}$ test $(\mathrm{p}<0.05) ;{ }^{3} \mathrm{CV}=\mathrm{Coefficient}$ of variation. 
Table 2. Evaluation of commercial lettuce cultivars for resistance to Meloidogyne incognita race 1 and M. javanica. Brasília, Embrapa, 2019.

\begin{tabular}{|c|c|c|c|c|c|}
\hline \multirow{2}{*}{ Cultivars } & \multirow{2}{*}{ Type } & \multicolumn{4}{|c|}{ M. incognita race 1} \\
\hline & & EMI $^{1}$ & GI $^{2}$ & NEGR $^{3}$ & $\mathrm{RF}^{4} /$ Reaction $^{5}$ \\
\hline Tainá & American & $4.70 \mathrm{a}$ & $5.00 \mathrm{a}$ & $9604.10 \mathrm{a}$ & $7.00 \mathrm{c}(\mathrm{S})$ \\
\hline Delícia & Crisp & $3.20 \mathrm{~b}$ & $5.00 \mathrm{a}$ & $1026.50 \mathrm{c}$ & $3.10 \mathrm{c}(\mathrm{S})$ \\
\hline Vanda & Crisp & $2.80 \mathrm{~b}$ & $3.30 \mathrm{~b}$ & $1862.30 \mathrm{~b}$ & $2.60 \mathrm{c}(\mathrm{S})$ \\
\hline Cinderela & Crisp & $2.20 \mathrm{c}$ & $2.00 \mathrm{c}$ & $134.10 \mathrm{c}$ & $1.40 \mathrm{~d}(\mathrm{~S})$ \\
\hline Veneranda & Crisp & $2.20 \mathrm{c}$ & $2.30 \mathrm{c}$ & $579.30 \mathrm{c}$ & $1.10 \mathrm{~d}(\mathrm{~S})$ \\
\hline Vera & Crisp & $2.30 \mathrm{c}$ & $2.30 \mathrm{c}$ & $522.80 \mathrm{c}$ & $0.80 \mathrm{~d}(\mathrm{R})$ \\
\hline Mônica & Crisp & $2.50 \mathrm{c}$ & $2.80 \mathrm{c}$ & $128.90 \mathrm{c}$ & $0.70 \mathrm{~d}(\mathrm{R})$ \\
\hline Babá de Verão & Smoth & $2.80 \mathrm{~b}$ & $3.60 \mathrm{~b}$ & $106.40 \mathrm{c}$ & $0.70 \mathrm{~d}(\mathrm{R})$ \\
\hline Amanda & Crisp & $1.80 \mathrm{c}$ & $2.00 \mathrm{c}$ & $46.70 \mathrm{c}$ & $0.60 \mathrm{~d}(\mathrm{R})$ \\
\hline Irene & American & $4.70 \mathrm{a}$ & $4.80 \mathrm{a}$ & $3983.80 \mathrm{~b}$ & $11.80 \mathrm{~b}(\mathrm{~S})$ \\
\hline Salinas 88 & American & $3.30 \mathrm{a}$ & $3.70 \mathrm{a}$ & $1636.70 \mathrm{~b}$ & 5.30 c (S) \\
\hline Grand Rapids & Crisp & $3.30 \mathrm{~b}$ & $3.50 \mathrm{~b}$ & $186.20 \mathrm{c}$ & $2.20 \mathrm{c}(\mathrm{S})$ \\
\hline Rutgers & Tomato & $4.80 \mathrm{a}$ & $5.00 \mathrm{a}$ & $3412.50 \mathrm{~b}$ & $25.40 \mathrm{a}(\mathrm{S})$ \\
\hline General mean & - & 3.24 & 3.62 & 1813.93 & 4.94 \\
\hline CV $(\%)$ & - & 8.63 & 7.79 & 69.32 & 22.07 \\
\hline \multicolumn{6}{|c|}{ M. javanica } \\
\hline Vera & Crisp & $2.70 \mathrm{~b}$ & $3.20 \mathrm{~b}$ & $1947.40 \mathrm{~b}$ & $4.90 \mathrm{~b}(\mathrm{~S})$ \\
\hline Amanda & Crisp & $2.20 \mathrm{~b}$ & $2.30 \mathrm{c}$ & $825.40 \mathrm{c}$ & $4.10 \mathrm{~b}(\mathrm{~S})$ \\
\hline Veneranda & Crisp & $1.60 \mathrm{c}$ & $2.20 \mathrm{c}$ & $3904.30 \mathrm{~b}$ & $2.70 \mathrm{~b}(\mathrm{~S})$ \\
\hline Cinderela & Crisp & $2.50 \mathrm{~b}$ & $3.20 \mathrm{~b}$ & $1141.30 \mathrm{c}$ & $2.20 \mathrm{~b}(\mathrm{~S})$ \\
\hline Vanda & Crisp & $2.00 \mathrm{~b}$ & $2.00 \mathrm{c}$ & $530.80 \mathrm{c}$ & $0.50 \mathrm{c}(\mathrm{R})$ \\
\hline Delícia & Crisp & $1.30 \mathrm{c}$ & $1.70 \mathrm{~d}$ & $342.40 \mathrm{c}$ & $0.40 \mathrm{c}(\mathrm{R})$ \\
\hline Mônica & Crisp & $1.80 \mathrm{c}$ & $2.80 \mathrm{c}$ & $514.60 \mathrm{c}$ & $0.40 \mathrm{c}(\mathrm{R})$ \\
\hline Babá de Verão & Smoth & $1.80 \mathrm{c}$ & $2.20 \mathrm{c}$ & $313.00 \mathrm{c}$ & $0.20 \mathrm{c}(\mathrm{R})$ \\
\hline Tainá & American & $1.80 \mathrm{~b}$ & $4.00 \mathrm{~b}$ & $913.30 \mathrm{c}$ & $0.10 \mathrm{c}(\mathrm{R})$ \\
\hline Irene & American & $2.80 \mathrm{~b}$ & $3.00 \mathrm{~b}$ & $2249.30 \mathrm{~b}$ & $3.40 \mathrm{~b}(\mathrm{~S})$ \\
\hline Salinas 88 & American & $1.30 \mathrm{c}$ & $1.70 \mathrm{~d}$ & $71.10 \mathrm{c}$ & $0.20 \mathrm{c}(\mathrm{R})$ \\
\hline Grand Rapids & Crisp & $1.70 \mathrm{c}$ & $1.30 \mathrm{~d}$ & $62.40 \mathrm{c}$ & 0.70 c (R) \\
\hline Rutgers & Tomato & $4.00 \mathrm{a}$ & $4.20 \mathrm{a}$ & $4653.00 \mathrm{a}$ & $29.80 \mathrm{a}(\mathrm{S})$ \\
\hline General mean & - & 2.31 & 2.64 & 1539.02 & 4.63 \\
\hline CV $(\%)$ & - & 8.82 & 7.90 & 68.49 & 22.04 \\
\hline
\end{tabular}

${ }^{1} \mathrm{EMI}$ and ${ }^{2} \mathrm{GI}=$ egg mass index and Gall Index according Taylor \& Sasser (1978); ${ }^{3} \mathrm{NEGR}=$ number of eggs per root gram; ${ }^{4} \mathrm{RF}: \mathrm{Reproduction}$ factor $=$ Final population/Initial population (5000 eggs and J2); ${ }^{5}$ Resistance reaction according to Oostenbrink $(1966): \mathrm{I}=\mathrm{Immune}(\mathrm{RF}=0)$; $\mathrm{R}=$ Resistant $(\mathrm{RF}<1)$ and $\mathrm{S}=$ Susceptible $(\mathrm{RF}>1)$. Averages followed by the same letter do not differ by Scott-Knott test $(\mathrm{p}<0.05)$.

susceptible to M. incognita. In that study 'Maravilha de Verão' and 'Verônica' were also susceptible.

Observing the three experiments, and comparing the two control cultivars considered resistant according to the literature, 'Salinas 88' was more resistant than 'Grand Rapids'. Cultivars Grand Rapids and Salinas 88 are widely used as resistance sources to the root-knot nematodes Meloidogyne incognita and M.javanica. It is assumed that the genetic resistance of Salinas 88 (Carvalho Filho et al., 2007) and Grand Rapids (Gomes et al., 2000) to M. incognita, are due to dominant genes with additive action for resistance. The different responses of these control cultivars in different experiments, for example, susceptibility of 'Salinas 88 ' to $M$. incognita in the second experiment and resistance in the third; and 'Grand
Rapids' as resistant to $M$. javanica in the second experiment and susceptible in the third, could be explained in lettuce, possibly by the environmental influence on the expression of resistance (Carvalho Filho et al, 2012), according to evidences found on 'Salinas 88 ' for race 1 of $M$. incognita which, despite being monogenic, is influenced by the presence of modifying genes that affect the expression of the character 
Table 3. Evaluation of commercial lettuce cultivars for resistance to Meloidogyne incognita race 1 and $M$. javanica. Brasília, Embrapa, 2019.

\begin{tabular}{|c|c|c|c|c|c|}
\hline \multirow{2}{*}{ Cultivars } & \multirow{2}{*}{ Type } & \multicolumn{4}{|c|}{ M. incognita race 1} \\
\hline & & EMI $^{1}$ & $\mathbf{G I}^{2}$ & NEGR $^{3}$ & $\mathbf{R F}^{4} /$ Reaction $^{5}$ \\
\hline BRS Leila & Crisp & $1.17 \mathrm{c}$ & $1.00 \mathrm{~d}$ & $265.93 \mathrm{~b}$ & $0.86 \mathrm{c}(\mathrm{R})$ \\
\hline BRS Mediterrânea & Crisp & $1.20 \mathrm{c}$ & $1.00 \mathrm{~d}$ & $81.68 \mathrm{~b}$ & $0.34 \mathrm{c}(\mathrm{R})$ \\
\hline Irene & American & $2.17 \mathrm{~b}$ & $2.17 \mathrm{~b}$ & $275.12 b$ & $1.38 \mathrm{c}(\mathrm{S})$ \\
\hline Grand Rapids & Crisp & $1.83 \mathrm{~b}$ & $1.67 \mathrm{c}$ & $753.89 \mathrm{~b}$ & $4.48 \mathrm{~b}(\mathrm{~S})$ \\
\hline Salinas 88 & American & $1.17 \mathrm{c}$ & $1.00 \mathrm{~d}$ & $162.99 \mathrm{~b}$ & $0.36 \mathrm{c}(\mathrm{R})$ \\
\hline Rutgers & Tomato & $5.00 \mathrm{a}$ & $5.00 \mathrm{a}$ & $14466.62 \mathrm{a}$ & 32.59 a $(\mathrm{S})$ \\
\hline Average mean & - & 2.09 & 1.97 & 2667.70 & 6.67 \\
\hline \multirow[t]{2}{*}{ CV $(\%)$} & - & 18.11 & 19.49 & 33.11 & 20.99 \\
\hline & \multicolumn{5}{|c|}{ M. javanica } \\
\hline BRS Leila & Crisp & $1.33 \mathrm{c}$ & $1.17 \mathrm{c}$ & $26.17 \mathrm{~b}$ & $0.12 \mathrm{c}(\mathrm{R})$ \\
\hline BRS Mediterrânea & Crisp & $1.00 \mathrm{c}$ & $1.00 \mathrm{c}$ & $50.28 \mathrm{~b}$ & $0.22 \mathrm{c}(\mathrm{R})$ \\
\hline Irene & American & $2.67 \mathrm{~b}$ & $2.50 \mathrm{~b}$ & $291.31 \mathrm{~b}$ & $1.12 \mathrm{c}(\mathrm{S})$ \\
\hline Grand Rapids & Crisp & $2.50 \mathrm{~b}$ & $2.17 \mathrm{~b}$ & $638.71 \mathrm{~b}$ & $4.14 \mathrm{~b}(\mathrm{~S})$ \\
\hline Salinas 88 & American & $1.00 \mathrm{c}$ & $1.00 \mathrm{c}$ & $121.42 \mathrm{~b}$ & $0.18 \mathrm{c}(\mathrm{R})$ \\
\hline Rutgers & Tomato & $5.00 \mathrm{a}$ & $5.00 \mathrm{a}$ & $31400.94 \mathrm{a}$ & 83.87 a (S) \\
\hline Average mean & - & 2.25 & 2.14 & 5421.07 & 14.94 \\
\hline CV (\%) & - & 19.03 & 19.53 & 32.62 & 26.66 \\
\hline
\end{tabular}

${ }^{1} \mathrm{EMI}$ and ${ }^{2} \mathrm{GI}=$ egg mass index and Gall Index according Taylor \& Sasser $(1978) ;{ }^{3} \mathrm{NEGR}=$ number of eggs per root gram; ${ }^{4} \mathrm{RF}$ : Reproduction factor $=$ Final population/Initial population (5000 eggs and J2); ${ }^{5}$ Resistance reaction according to Oostenbrink (1966): I= Immune (RF= $0) ; \mathrm{R}=$ Resistant $(\mathrm{RF}<1)$ and $\mathrm{S}=$ Susceptible $(\mathrm{RF}>1)$. Averages followed by the same letter do not differ by Scott-Knott test $(\mathrm{p}<0.05)$.

(Carvalho Filho et al, 2008); that is, despite being a qualitative character, it can behave as quantitative and be influenced more significantly by the environment. Therefore, the probability of resistance of these cultivars is not very stable in the face of experimental or environmental conditions.

Therefore, it was possible to conclude, based on the amount of galls formed in the roots, that the cultivars with crisp leaf type presented a higher degree of resistance to the root-knot nematodes compared to the cultivars of the smooth type; the cultivars Vera and Amanda present resistance to $M$. incognita, and Vanda to M. javanica. 'Salinas 88 ' present resistance mainly to $M$. javanica; whereas the cultivar Mônica and the cultivars of Embrapa, BRS Leila and BRS Mediterrânea, are resistant to both nematode species. These results are important to direct crosses aiming to develop new resistant lettuce cultivars, also for the productive sector, that can use the cultivars characterized as resistant for the management of the disease in the field.

\section{REFERENCES}

CAMPOS, VP; CAMPOS, JR; SILVA, LHCP; DUTRA, MR. 2001. Manejo de nematoides em hortaliças. In: SILVA, LHCP; CAMPOS, JR; NOJOSA, CBA (eds). Manejo integrado: doenças e pragas em hortaliças. Lavras: UFLA. p.125-158.

CARVALHO FILHO, JLS; GOMES, LAA; WESTERICH, JN; MALUF, WR; CAMPOS, VP. 2007. Caracterização de famílias F4 de alface de folhas lisas quanto à homozigose para resistência à Meloidogyne incognita. Revista Brasileira de Agrociência 13: 336-342.

CARVALHO FILHO, JLS; GOMES, LAA; WESTERICH, JN; MALUF, WR; CAMPOS, VP; FERREIRA, S. 2008. Inheritance of resistance of Salinas 88 lettuce to the root-knot nematode Meloidogyne incognita (Kofoid
\& White) Chitwood. Revista Brasileira de Agrociência 14: 279-289.

CARVALHO FILHO, JS; GOMES, LA; CARVALHO, RRC. 2012. Incidência de galhas de Meloidogyne incognita raça $1 \mathrm{em}$ progênies de F2:3 ('Salinas 88' x 'Colorado') de alface. Scientia Plena 8: 1-7.

CHARCHAR, JM; MOITA, AW. 1996. Reação de cultivares de alface a infecção por mistura de populacionais de Meloidogyne incognita raça 1 e M. javanica em condição de campo. Horticultura Brasileira 14: 185-189.

CORREIA, ÉCSS; SILVA, ND; COSTA, MGS; WILCKEN, SRS. 2019. Response of lettuce cultivars to Meloidogyne javanica and Meloidogyne incognita race 1 and 2. Revista Ciência Agronômica 50: 100-106.

CRUZ, CD. 2016. Genes Software-extended and integrated with the R, Matlab and Selegen. Acta Scientiarum Agronomy 38: 547-552.

DUTRA, MR; CAMPOS, VP; TOYOTA, M. 2003. Manejo do solo e da irrigação para o controle de Meloidogyne javanica em alface. Nematologia Brasileira 27: 29-34.

FERNANDES, AM; KULCZYNSKI, SM. 2009. Reações de cultivares de alface a Meloidogyne incognita. Agrarian 2: 143-148.

FERREIRA, S; GOMES, LAA; GASPARINO, CF; CARVALHO FILHO, JLS; MALUF, WR. 2013. Caracterização de famílias F2:3 de alface para resistência ao nematoide de galhas. Revista Agrogeoambiental 5: 35-42.

FERREIRA, TA; TAVARES, AT; SILVA, EHC; VENTURA, LVR; NASCIMENTO, IRN. 2018. Reação de cultivares de alface a Meloidogyne raça 1 e 2, em condições de temperatura elevada. Pesquisa Aplicada \& Agrotecnologia 11: 31-39.

GOMES, LAA; MALUF, WR; CAMPOS, VP. 2000. Inheritance of the resistance reaction of the lettuce cultivar 'Grand Rapids' to the southern root-knot nematode Meloidogyne incognita (Kofoid \& White) Chitwood. Euphytica 114: 34-46.

LIBÂNIO, RA. 2005. Obtenção de híbridos de pimentão com resistência a nematoides de galhas Meloidogyne incognita. Lavras: UFLA. 69p. (M.Sc. Thesis).

MENDES, WP. 1998. Hospedabilidade e resistência de cultivares de alface (Lactuca sativa L.) aos nematóides de galhas Meloidogyne incognita (raça 1, 3 e 4) e Meloidogyne javanica. Lavras: UFLA. 43p. (M.Sc. Thesis).

OLIVEIRA, GHF; SANTANA, SEREA; FONSECA, RCN; LIMA, LE; GOMES, LAA; CARVALHO FILHO, JELS. 2015. Meloidogyne incognita resistant strains of leaf lettuce. African Journal of Agricultural Research 10: 4660-4667.

OOSTENBRINK, M. 1966. Major characteristics of the relation between nematodes and plants. Mededelingen Landbouw 66: 1-46.

PINHEIRO, JB. 2017. Nematoides em Hortaliças. $1^{\circ}$. ed. Brasília: Embrapa Hortaliças, v1. 194p. RABELLO, LKC. 2010. Quantificação de danos e perdas causados por Meloidogyne javanica 
em alface (Lactuca sativa L.). Vitória: UFES. 50p. (M.Sc. Thesis).

SOARES, RS. 2017. Reação de genótipos de Capsicum annuum a nematoides de galha. Jaboticabal: UNESP. 56p. (M.Sc. Thesis).

TAYLOR, AL; SASSER, JN. 1978. Biology, identification and control of root-knot nematodes (Meloidogyne species). Raleigh: North Caroline University Graphics, 111p.

WILCKEN, SRS; GARCIA, MJM; SILVA, N. 2005. Resistência de alface do tipo Americana a Meloidogyne incognita raça 2. Nematologia
Brasileira 29: 267-271.

WILCKEN, SRS; GARCIA, MJM; SILVA, N. 2004. Reprodução de Meloidogyne incognita raça $2 \mathrm{em}$ diferentes cultivares de alface (Lactuca sativa L.). Arquivos do Instituto Biológico 71: 379-381. 